Article

\title{
Biochar, Vermicompost, and Compost as Soil Organic Amendments: Influence on Growth Parameters, Nitrate and Chlorophyll Content of Swiss Chard (Beta vulgaris L. var. cycla)
}

\author{
Angela Libutti ${ }^{1, *(D)}$, Vincenzo Trotta ${ }^{2}$ and Anna Rita Rivelli ${ }^{3}$ \\ 1 Department of Science of Agriculture, Food and Environment, University of Foggia, Via Napoli, 25, \\ 71122 Foggia, Italy \\ 2 Department of Science, University of Basilicata, Via dell'Ateneo Lucano, 10, 85100 Potenza, Italy; \\ vincenzo.trotta@unibas.it \\ 3 School of Agricultural, Forest, Food and Environmental Sciences, University of Basilicata, \\ Via dell'Ateneo Lucano, 10, 85100 Potenza, Italy; annarita.rivelli@unibas.it \\ * Correspondence: angela.libutti@unifg.it; Tel.: +39-0881-589-228
}

Received: 7 February 2020; Accepted: 28 February 2020; Published: 3 March 2020

\begin{abstract}
Soil addition with organic amendments is an issue that receives growing attention in the agricultural sector. However, the effects of such materials on plant growth and crop yield are highly variable in the literature. This study aims to evaluate the influence of soil addition with biochar (from vine pruning residues), vermicompost (from cattle manure), and three different composts (from olive pomace or cattle anaerobic digestate), on the quali-quantitative response of Swiss chard (Beta vulgaris L. var. cycla) grown in pots. The organic amendments were applied to the soil in two doses to provide 140 and $280 \mathrm{~kg} \mathrm{~N} \mathrm{ha}^{-1}$, respectively. Two growth cycles were considered, and, at each leaf cut, plants were analyzed for growth parameters (height, fresh weight, leaf number, and leaf area) and qualitative characteristics (nitrogen, nitrate, and pigment leaf content). Swiss chard responded positively to organic amendment and, particularly when the soil was treated with compost from animal wastes, higher plant growth and pigment leaf content were observed. Nitrate leaf content was always well below the $\mathrm{NO}_{3}{ }^{-}$thresholds established by the European Commission Regulations. Biochar application did not show a positive effect on the quali-quantitative characteristics of Swiss chard, likely due to benefits that may be achieved over time.
\end{abstract}

Keywords: soil organic amendment; animal wastes; compost; vermicompost; biochar; nitrate leaf content; chlorophyll content; SPAD meter values

\section{Introduction}

Swiss chard (Beta vulgaris L. var. cycla) has been grown in Europe since antiquity and is now widely cultivated in many temperate regions of the world for its edible leaves and stalks. The leaves can be used in salads or cooked like spinach, while the stalks are usually chopped and cooked like celery. This vegetable represents a cheap and rich source of nutrients, available all year round. Both the leaves and stalks contain considerable nutritionally concentrations of vitamins (A, K, E, C, B3, B5, B9) and minerals (iron, potassium, calcium, phosphorus, and magnesium), dietary fibers and proteins, phytopigments such as chlorophyll and carotenoids, flavonoids and phenolic compounds including several phenolic acids with high free-radical scavenging capacity and antioxidant activity [1-4]. These properties make Swiss chard attractive for numerous health benefits and for reducing the risk of neurodegenerative and chronic diseases. However, the leaves of the species can also contain a 
considerable concentration of anti-nutritional factors such as oxalates and particularly nitrates [3,5]. According to Santamaria et al. [5], Swiss chard tends to accumulate more nitrates than other species, with over $60 \%$ of total nitrate content in the petioles. The authors also report that the mean daily vegetable nitrate intake (approximately $71 \mathrm{mg}$ in Italy) come from lettuce, Swiss chard, and beetroot, which together accounted for $47 \%$ of daily intake. Acceptable nitrate daily intake, risks for human health, and limits to maximum levels of nitrate in vegetables are discussed in Santamaria [6]. According to the author, several factors affect the uptake and accumulation of nitrate in vegetables, as genetic factors (species and cultivar), environmental factors (temperature, light intensity, and photoperiod, soil nitrogen content), and agriculture practices (primarily nitrogen doses and chemical forms). As reported by Pokluda and Kuben [7], the nutritional value of Swiss chard is generally dependent on cultivars and varieties, but to a much greater extent on leaf portion (blades and petioles) and growing season (spring and autumn) [8]. Besides climate and environmental conditions, Ivanović et al. [1] reported that the nutritional and phytochemicals content, as well as the yield of Swiss chard, also depends on irrigation and fertilization. About this latter, the quality and yield of Swiss chard are strongly influenced by the amount, frequency, type, and method of fertilization. In addition to water pollution problems, intensive application of nitrogen fertilizers, particularly in the form of nitrates, may determine an excess of nitrogen in fresh-cut leafy vegetables, causing serious risks for human health and the environment [9]. Several studies focused on the effects of different forms and rates of mineral nitrogen fertilizers on Swiss chard quality $[2,8,10,11]$, showing that high levels of $\mathrm{N}$ fertilizer, although they increase the production, compromise the quality of fresh-cut yield. The range between 100 and $150 \mathrm{~kg} \mathrm{~N} \mathrm{ha}^{-1}$ is recommended for the species to meet yield level, production cost, and leaf quality, allowing to keep low nitrate content below safe limits and avoid a negative impact on leaf nutritional value. In a survey study on nitrate content of 22 vegetable species produced in Tunisia under organic and conventional farming systems [12], significant differences were observed in Swiss chard nitrate content (1176 vs. $2243 \mathrm{mg} \mathrm{kg}^{-1}$ fresh weight-Fw, respectively).

As an alternative to mineral fertilization, there is currently a growing interest in exploring the benefits and opportunities as well as the limitations in the use of organic amendments, as compost and biochar, to enhance plant nutrition, crop yield and quality, protect soil fertility, and ensure environmental sustainability of crop production [13-17]. Compost is the product of organic waste stabilization and sanitation through aerobic decomposition process, under controlled conditions [13]. Biochar is a carbon-rich, solid material obtained by biomass (manure, sewage sludge, wood biomass and crop residues) pyrolysis in an oxygen-limited environment [18-21]. The effects of their addition to agricultural soils depend on a number of factors, including feedstock properties and processing conditions, application rate, soil type, environmental conditions, and crop species [22,23]. About the latter, the yield response to compost or biochar applications are often contrasting; generally, either positive or negative and sometimes also neutral effects on crop yield and quality have been reported [13,24]. In Swiss chard, Paredes et al. [25] found no significant differences on plant growth and yield comparing inorganic fertilizer and two doses of compost from olive mill wastewater; while other authors using a vermicompost mixed with coir for container-grown plants [26] or compost from organic domestic wastes and crop residues [27] observed higher growth and yield increases. As to biochar, Trupiano et al. [28] found that this amendment stimulated leaves number and total biomass of lettuce in soil poor in nutrients. In a comparison of the efficacy of peanut shell biochar and biochar-based compost on crown daisy and lettuce productivity, biochar had little effect on crop growth and mass yield [29]. In a pot experiment [30], the addition of rice-husk biochar to soil with and without fertilizers (a mixture of compost, liquid compost, and lake sediments) increased the final biomass, root biomass, plant height and leaves number of lettuce and Chinese cabbage.

In this context, we report an experimental study aimed at assessing whether soil addition with different types of organic amendments can affect quantitative and qualitative characteristics of Swiss chard (Beta vulgaris L. var. cycla), a fresh-cut vegetable largely consumed in Italy as "erbetta da taglio". For this purpose, a pot short-term experiment, where Swiss chard plants were grown on soil amended 
with a biochar (from vine pruning residues), a vermicompost (from cattle manure), and three different composts (from olive pomace and cattle anaerobic digestate), was carried out in order to evaluate plant growth, nitrogen, nitrate, and leaf pigment content.

\section{Materials and Methods}

\subsection{Experimental Layout}

A greenhouse experiment was carried out during 2017 in Potenza (Southern Italy) at the University of Basilicata (PZ, $40^{\circ} 38^{\prime} \mathrm{N} 15^{\circ} 48^{\prime} \mathrm{E}, 819 \mathrm{~m}$ a.s.l.) on Swiss chard (Beta vulgaris L. var. cycla), grown in pots containing soil treated with different types of organic amendments. More specifically, the experimental design included: Non-treated soil or control (NT); soil treated with biochar produced by pyrolysis of vine pruning residues (B); soil treated with compost obtained from olive pomace (COP); soil treated with vermicompost obtained from cattle manure (CW); soil treated with composts obtained from $90 \%$ cattle anaerobic digestate with $10 \%$ wheat straw addition (CD1); soil treated with compost obtained from $79 \%$ cattle anaerobic digestate with $11 \%$ crop residues and $10 \%$ wheat straw addition (CD2). Each organic amendment was applied to the soil in 2 different doses, in order to provide 140 and $280 \mathrm{~kg} \mathrm{~N} \mathrm{ha}^{-1}$, respectively (single and double dose). Considering the total nitrogen content of each amendment, an amendment application within the $0.15 \mathrm{~m}$ soil depth and a soil bulk density of $1.3 \mathrm{Mg} \mathrm{m}^{-3}$, the single and double doses corresponded to: 10-20, 9.5-19, 12-24, 13-26, and 10-20 $\mathrm{Mg} \mathrm{ha}^{-1}$ as fresh matter for $\mathrm{B}, \mathrm{COP}, \mathrm{CW}, \mathrm{CD} 1$, and $\mathrm{CD} 2$, respectively.

The soil used in the experiment was collected from an agricultural field located in the Potenza district (Southern Italy), whose characteristics are detailed below (Table 1). About the amendments, the biochar was obtained from vine pruning residues, through a pyrolysis process carried out in a pilot-scale fixed bed reactor, at the STAR*Facility Centre of Foggia University (Foggia, Southern Italy). Pruning biomass was pyrolyzed in a tubular reactor ( $30 \mathrm{~L}$ capacity), at a reaction temperature of $650{ }^{\circ} \mathrm{C}$ for eight hours. Vermicompost and composts were purchased from two industrial plants, which process organic residues from olive mills, crops, and livestock to produce high-quality soil amendments, respectively, located at Eboli (Salerno district, Italy) and Montescaglioso (Matera district, Italy).

Two months after the application of the organic amendments to the soil, seedlings of Swiss chard, cultivar "Eolo", were transplanted singly into $13 \times 13 \times 24 \mathrm{~cm}$ pots, containing a $2 \mathrm{~cm}$ layer of expanded clay on the bottom to improve water drainage and $2 \mathrm{~kg}$ of non-treated or treated soil. The soil surface was covered with a $3 \mathrm{~cm}$ layer of polythene beads to prevent water losses by evaporation. In the course of the trial, pots were watered every 2-3 days, given approximately $120 \mathrm{~mL}$ of water. The experiment was laid out in a randomized complete block design with the six soil treatments and the 2 amendment doses each replicated 4 times.

\subsection{Characterization of Soil and Organic Amendments}

Before starting the experiment, a soil physico-chemical characterization was performed. The soil particle-size distribution was determined using the pipette-gravimetric method. The $\mathrm{pH}$ and electrical conductivity $(\mathrm{EC})$ were measured on 1:2.5 (w/v) aqueous soil extracts and the saturated soil paste extracts, by a GLP 22+ pH-meter and a GLP 31+ EC-meter (Crison Instruments, Barcelona), respectively. The available phosphorus was determined by the sodium bicarbonate method [31], and the total organic carbon by the Walkley-Black acid dichromate digestion technique [32]. The organic matter was appraised by multiplying the percentage of the organic carbon by the factor 1.724 . The $\mathrm{Na}^{+}$, $\mathrm{Ca}^{2+}, \mathrm{Mg}^{2+}$, and $\mathrm{K}^{+}$were determined in soil saturated paste extracts and analyzed by using Atomic Absorption Spectroscopy-AAS (Perkin-Elmer Atomic Absorption Spectrophotometer-model 2380). The total nitrogen was obtained according to the Kjeldahl method [33] and the nitrate $\left(\mathrm{NO}_{3}{ }^{-}\right)$content was determined by soil extraction with $2 \mathrm{M} \mathrm{KCl}$, followed by spectrophotometric analysis of the extract [34]. 
The information about the main physico-chemical characteristics detected on the soil are reported in Table 1.

Table 1. Main physico-chemical properties of the soil utilized in the experiment.

\begin{tabular}{cc}
\hline Property & Value \\
\hline Clay (\%) & $22.40 \pm 0.72$ \\
Silt (\%) & $11.50 \pm 0.81$ \\
Sand (\%) & $66.10 \pm 0.81$ \\
pH (-) & $7.50 \pm 0.08$ \\
$\mathrm{EC}\left(\mathrm{dS} \mathrm{m}^{-1}\right)$ & $0.42 \pm 0.12$ \\
Olsen $\mathrm{P}_{2} \mathrm{O}_{5}\left(\mathrm{mg} \mathrm{kg}^{-1}\right)$ & $28.00 \pm 0.61$ \\
Organic carbon $\left(\mathrm{g} \mathrm{kg}^{-1}\right)$ & $7.90 \pm 0.74$ \\
Organic matter $(\%)$ & $1.40 \pm 0.74$ \\
$\mathrm{C} / \mathrm{N}(-)$ & $7.20 \pm 0.82$ \\
Total nitrogen $\left.(\%)^{-1}\right)$ & $1.10 \pm 0.53$ \\
$\mathrm{NO}_{3}^{-}\left(\mathrm{mg} \mathrm{kg}^{-1}\right)$ & $48.00 \pm 0.32$ \\
$\mathrm{Na}^{+}\left(\mathrm{mg} \mathrm{kg}^{-1}\right)$ & $25.00 \pm 0.38$ \\
$\mathrm{Ca}^{2+}\left(\mathrm{mg} \mathrm{kg}^{-1}\right)$ & $3289.00 \pm 0.89$ \\
$\mathrm{Mg}^{2+}\left(\mathrm{mg} \mathrm{kg}^{-1}\right)$ & $215.00 \pm 0.91$ \\
$\mathrm{~K}^{+}\left(\mathrm{mg} \mathrm{kg}^{-1}\right)$ & $368.00 \pm 0.78$ \\
\hline
\end{tabular}

Values are means $(\mathrm{n}=3) \pm$ standard errors.

Biochar, vermicompost, and composts were analyzed for a set of chemical properties. The $\mathrm{pH}$ and electrical conductivity were determined in deionized water $(1: 20 \mathrm{w} / \mathrm{v})$, followed by shaking and waiting an equilibrium time of 90 min before measurement by a GLP 22+ pH-meter and a GLP 31+ EC-meter (Crison Instruments, Barcelona), respectively. The proximate analysis determined the relative content in fixed carbon, volatile solids, ash, and moisture, using a TGA analyzer unit (LECO-TGA701) according to the ASTM D7582 method. The ultimate analysis determined the $\mathrm{C}, \mathrm{N}$, and $\mathrm{H}$ content by dry combustion, using a CHN Elemental Analyser (CHN LECO 680) according to the method LECO-ASTM D5373. In the case of Corg, combustion was carried out after the complete removal of inorganic $\mathrm{C}$ with acid. For biochar, from hydrogen $(\mathrm{H})$ and carbon $(\mathrm{C})$ content, the molar ratios of hydrogen to organic carbon $\left(\mathrm{H} / \mathrm{C}_{\mathrm{org}}\right)$ was obtained.

Chemical properties of biochar, vermicompost, and composts are summarized in Table 2. The biochar showed a $\mathrm{pH}$ within the range of alkalinity, which is the typical value for the majority of biochar [35], and an EC value higher than that of the receiving soil. The total carbon (C) and the organic carbon $\left(\mathrm{C}_{\text {org }}\right)$ contents were well within the thresholds of the European Biochar Certificate [36] and according to the Class 1 of IBI-Standard [37], respectively. In addition, $\mathrm{H} / \mathrm{C}_{\text {org }}$ molar ratio was found to meet the EBC and IBI-Standard requirements $\left(\mathrm{H} / \mathrm{C}_{\text {org }} \leq 0.7\right)$. Lower $\mathrm{H} / \mathrm{C}_{\text {org }}$ ratios provided indications of long-term stability and persistence of biochar in the soil, contributing to carbon sequestration [38]; on the contrary, $\mathrm{H} / \mathrm{C}_{\text {org }}$ values exceeding 0.7 were an indication of non-pyrolytic chars or pyrolysis deficiencies [39]. Vermicompost and composts proven to be mature and stable in terms of chemical characteristics, as reported in Table 2. Differently from biochar, they were neutral or slightly alkaline and resulted in a higher total $\mathrm{N}$ content. In addition, vermicompost and composts had a higher EC than the soil. Composts both from olive pomace (COP) and from cattle digestate (CD1 and CD2) showed a higher total $\mathrm{N}$ content than vermicompost $(\mathrm{CW})$. Moreover, $\mathrm{COP}$ contained more $\mathrm{C}_{\mathrm{org}}$, which was very similar to $\mathrm{C}_{\text {org }}$ detected on biochar and more than double of $\mathrm{C}_{\text {org }}$ detected on $\mathrm{CW}, \mathrm{CD} 1$, and CD2. 
Table 2. Main chemical properties of biochar, vermicompost, and composts applied to the soil.

\begin{tabular}{cccccc}
\hline Property & B & COP & CW & CD1 & CD2 \\
\hline pH & $11.26 \pm 0.07$ & $7.92 \pm 0.03$ & $7.64 \pm 0.07$ & $6.89 \pm 0.02$ & $8.74 \pm 0.04$ \\
EC $\left(\mathrm{dS} \mathrm{m}^{-1}\right)$ & $3.63 \pm 0.15$ & $2.35 \pm 0.05$ & $2.65 \pm 0.03$ & $4.33 \pm 0.05$ & $1.95 \pm 0.01$ \\
Fixed carbon $(\%)$ & $69.77 \pm 0.04$ & $3.93 \pm 0.10$ & $0.53 \pm 0.04$ & $2.35 \pm 0.02$ & $2.37 \pm 0.04$ \\
Volatile solids $(\%)$ & $16.95 \pm 0.03$ & $53.87 \pm 0.03$ & $32.34 \pm 0.09$ & $44.61 \pm 0.14$ & $69.77 \pm 0.01$ \\
Ash (\%) & $13.28 \pm 0.03$ & $42.20 \pm 0.11$ & $67.13 \pm 0.09$ & $53.04 \pm 0.10$ & $27.85 \pm 0.12$ \\
Moisture (\%) & $5.22 \pm 0.04$ & $28.75 \pm 0.10$ & $35.45 \pm 0.08$ & $54.55 \pm 0.40$ & $33.96 \pm 0.10$ \\
C (\%) & $67.70 \pm 0.30$ & $60.90 \pm 1.23$ & $25.20 \pm 0.10$ & $24.50 \pm 0.63$ & $34.50 \pm 0.34$ \\
H $(\%)$ & $2.36 \pm 0.06$ & $4.55 \pm 0.22$ & $1.36 \pm 0.17$ & $2.17 \pm 0.20$ & $4.44 \pm 0.06$ \\
N (\%) & $1.48 \pm 0.02$ & $2.61 \pm 0.11$ & $1.62 \pm 0.01$ & $2.27 \pm 0.12$ & $2.59 \pm 0.02$ \\
Corg $(\%)$ & $66.74 \pm 0.04$ & $56.30 \pm 0.14$ & $20.05 \pm 0.18$ & $23.33 \pm 0.58$ & $26.56 \pm 0.63$ \\
C/N & $45.10 \pm 0.76$ & $21.57 \pm 0.84$ & $12.38 \pm 0.08$ & $10.31 \pm 0.56$ & $10.25 \pm 0.29$ \\
H/C org ratio & $0.42 \pm 0.01$ & - & - & - & - \\
\hline
\end{tabular}

B, biochar; COP, compost from olive pomace; CW, vermicompost from cattle manure; CD1, compost from $90 \%$ cattle anaerobic digestate with $10 \%$ wheat straw addition; $C D 2$, compost from $79 \%$ cattle anaerobic digestate with $11 \%$ crop residues and $10 \%$ wheat straw addition. Values are means $(n=3) \pm$ standard errors.

\subsection{Analysis of Plant Growth Parameters}

Starting from 10 days after transplanting (DAT), the growth of the seedlings was monitored through an accurate counting of the leaf number, carried out twice per week.

As foreseen by the production specifications of Swiss chard, the cuts of the marketable leaves were scheduled at the end of two growth cycles, each lasting about 4 weeks. The first cut was made at 34 DAT, taking care to not blind the plant, thus allowing the subsequent development of the newly formed basal leaflets; the second cut was made at 60 DAT.

At the end of each growth cycle, before leaf cutting, the height of the plant $(\mathrm{H})$ from the soil line to the top of the longest leaf was measured. Then, leaves were cut, cleaned with tap water, dried with paper towels, counted, weighed to determine the fresh weight (FW), and scanned to measure the leaf area (LA) by using an LI-COR leaf area meter (Model 3100, Inc., Lincoln, NE, USA). Finally, leaves were dried in a ventilated oven at $70^{\circ} \mathrm{C}$ until a steady weight to determine the dry weight (DW).

\subsection{Analysis of Nitrogen, Nitrate, and Pigment Leaf Content}

Dried leaf tissue was analyzed for nitrogen and nitrate content. The nitrogen (total $\mathrm{N}$ ) content was determined by the Kjeldahl method [33]. Nitrate $\left(\mathrm{NO}_{3}{ }^{-}\right)$content was measured by the colorimetric method on leaf water extract added to salicylic acid in concentrated sulfuric acid, as performed by Cataldo et al. [40]. The complex formed by nitration of salicylic acid under highly acidic conditions absorbs maximally at $410 \mathrm{~nm}$ in basic $(\mathrm{pH}>12)$ solutions. The absorbance of the chromophore was directly proportional to the amount of nitrate present in the sample.

Before the first cut of the leaves, chlorophyll leaf content was estimated using a hand-held SPAD $502 \mathrm{~m}$ (Konica-Minolta corporation, Ltd., Osaka, Japan). Average SPAD chlorophyll readings were calculated from 3 measurements from the tip to the base of the youngest fully expanded leaf $\left(\mathrm{SPAD}_{\text {leaf }}\right)$ and of all the leaves per plant $\left(\mathrm{SPAD}_{\text {plant }}\right)$. Subsequently, a sample of fresh tissue from each of the 4 plants per treatment was collected to measure the leaf content of the following pigments: Chlorophyll a (CHL a), chlorophyll b (CHL b), and carotenoids (CA). Briefly, fresh leaf tissues were ground with a glass homogenizer in $2 \mathrm{~mL} 80 \%$ acetone $(\mathrm{v} / \mathrm{v})$. The homogenate was centrifuged at $2300 \mathrm{~g}$ for $2 \mathrm{~min}$, and CHL a, CHL b, and CA contents were, respectively, calculated from absorbances at 646.6, 663.6 [41], and $480 \mathrm{~nm}$ [42]. Total chlorophyll (CHL) was determined as the sum of CHL a and CHL b. CHL values correlated well $\left(\mathrm{R}^{2}=0.88\right.$ ) with SPAD readings (data not shown). Therefore, the SPAD chlorophyll readings were used to give an accurate and rapid estimate of total chlorophyll leaf content during the second growth cycle. 


\subsection{Statistical Analysis}

Data were analyzed using a mixed linear model ANOVA in which "amendment" (fixed effect, six levels: NT, B, COP, CW, CD1, and CD2) and "dose" (random effect, two levels: 140 and $280 \mathrm{~kg} \mathrm{~N}$ $\mathrm{ha}^{-1}$ ) were the main effects, followed by Duncan test at $p \leq 0.05$. This analysis was used to test for amendment $(A)$ and dose $(D)$ differences, as well as for their interaction $(A \times D)$. Significant levels were expressed as ${ }^{*} p \leq 0.05,{ }^{* *} p \leq 0.01$ and ${ }^{* * *} p \leq 0.001$.

\section{Results}

\subsection{Plant Growth Parameters}

Figure 1 shows the number of leaves produced by Swiss chard plants during the two considered growth cycles, respectively, completed at 34 and 60 DAT. The total leaf number detected at 34 and 60 DAT (at the first and second cut, respectively) statistically differed between cuts $(p \leq 0.001)$, amendments $(p \leq 0.05)$, doses $(p \leq 0.05)$, and cuts $\mathrm{x}$ doses interaction $(p \leq 0.05)$. During the two growth cycles, leaf number increased over time, reaching, on average, a higher value at the first $(17.7 \pm 0.4)$ than the second cut $(9.8 \pm 0.3)$. Among amendments, $\mathrm{CW}$ showed the highest leaf number both at the first and at the second cut $(21.5 \pm 2.4$ and $13.3 \pm 1.6$, respectively). The plants treated with B produced a lower number of leaves than the plants treated with the other organic amendments (on average 17.5 and 8.6, respectively at the first and the second cut) that did not differ from the non-treated plants (NT). Except for B, the number of leaves in each treatment was generally higher when the double dose ( $280 \mathrm{~kg} \mathrm{~N} \mathrm{ha}^{-1}$ ) was applied compared to the single one $\left(140 \mathrm{~kg} \mathrm{~N} \mathrm{ha}^{-1}\right)$. Considering the two cuts and the two amendment application doses as a whole, the number of leaves produced by Swiss chard plants ranged, on average, from a minimum value of 26.3 in NT and B to a maximum value of 32.2 in CW (29.5 and 34.8, single and double dose, respectively).

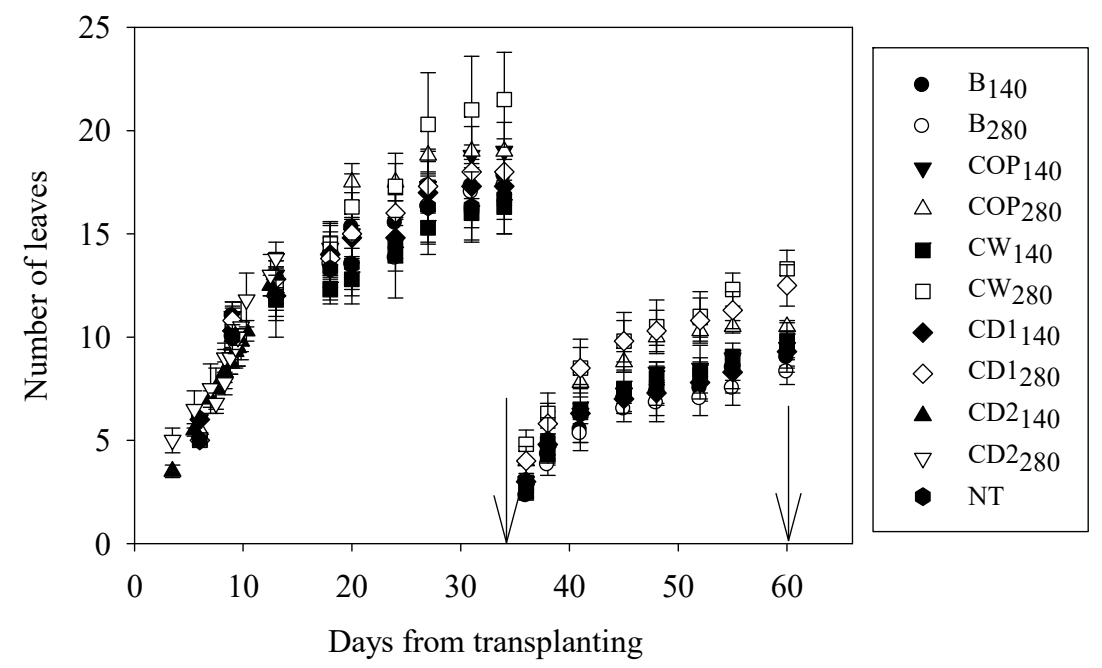

Figure 1. Number of leaves produced during 60 days after transplanting by Swiss chard plants treated with different organic amendments $(\mathrm{B}$, biochar; $\mathrm{COP}$, compost from olive pomace; $\mathrm{CW}$, vermicompost from cattle manure; $\mathrm{CD} 1$, compost from $90 \%$ cattle anaerobic digestate with $10 \%$ wheat straw addition; CD2, compost from $79 \%$ cattle anaerobic digestate with $11 \%$ crop residues and $10 \%$ wheat straw addition), each added to provide 140 and $280 \mathrm{of} \mathrm{kg} \mathrm{N} \mathrm{ha}^{-1}$ (black and white symbols, respectively), plus a non-treated soil or control (NT). The arrows indicate the first and second leaf cut (at 34 and 60 DAT, respectively). Values are means $(n=4) \pm$ standard errors.

Figure 2 reports the height $(\mathrm{H})$, leaf area (LA), and fresh weight $(\mathrm{FW})$ values recorded at the first and second cut of Swiss chard. Considering the first cut, $\mathrm{H}$ and LA (Figure 2a,c, respectively) were significantly influenced by organic amendments $(p \leq 0.001)$. Higher $\mathrm{H}$ and LA values were measured on 
plants treated with amendments from animal wastes $\left(13.5 \mathrm{~cm}\right.$, and $175 \mathrm{~cm}^{2}$, respectively, as average of $\mathrm{CW}, \mathrm{CD1}$, and CD2), followed by compost from olive pomace (COP) $\left(12.3 \mathrm{~cm}\right.$, and $140 \mathrm{~cm}^{2}$, respectively) and then biochar (B) $\left(10.0 \mathrm{~cm}\right.$, and $103 \mathrm{~cm}^{2}$, respectively) that did not differ from non-treated plants (NT) $\left(10.6 \mathrm{~cm}\right.$, and $120 \mathrm{~cm}^{2}$, respectively). The plant height was significantly influenced by organic amendments $x$ doses interaction $(p \leq 0.05)$. Particularly, the highest value of $\mathrm{H}(15.7 \mathrm{~cm})$ was detected in plants treated with a double dose of CD2. Considering the plant weight, the FW values (Figure 2e) were always statistically different among the organic amendments $(p \leq 0.001)$ and between the two doses $(p \leq 0.05)$ applied to the soil. When the soil was treated with the double dose of CW, CD1, and CD2, significantly higher values of FW (10.1, 8.0, and $11.1 \mathrm{~g}$, respectively) were observed. On average, by adding amendments from animal wastes (CW, CD1, CD2) and olive pomace (COP) increases of $41.6 \%$ and $12.5 \%$ of FW were, respectively, observed in comparison to non-treated plants (NT), while a decrease of $16 \%$ was detected in plants treated with biochar (B). Furthermore, again in plants treated with CW, CD1, and CD2, FW increased by $25 \%$ on average when the double dose of amendments was applied. On the contrary, FW did not statistically differ between plants treated with COP and B, respectively. Considering both LA and FW values, the interaction between type and dose of organic amendments applied to the soil was not statistically significant.
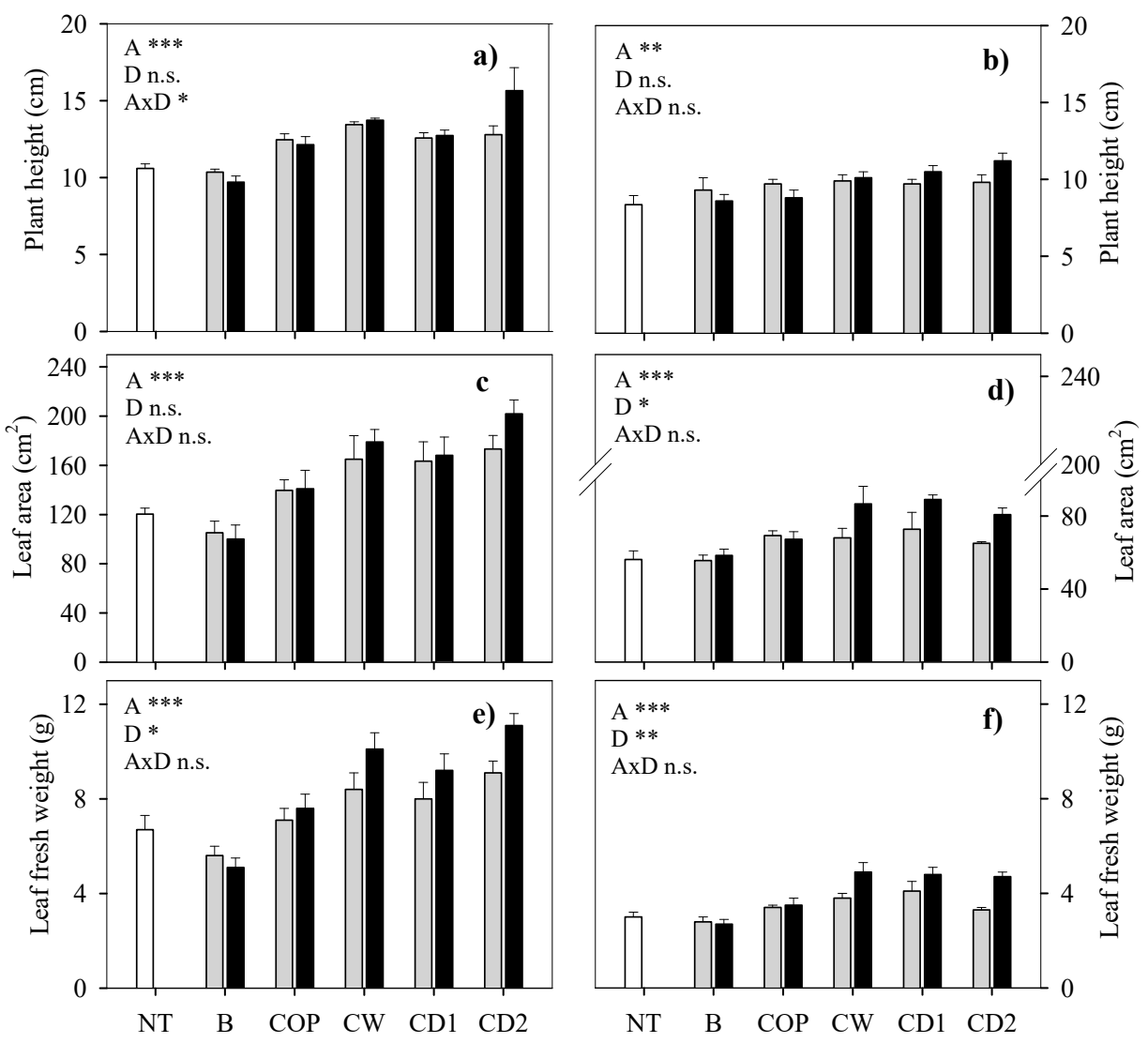

Figure 2. Plant height $(\mathbf{a}, \mathbf{b})$, leaf area $(\mathbf{c}, \mathbf{d})$ and leaf fresh weight $(\mathbf{e}, \mathbf{f})$ of Swiss chard treated with different organic amendments $(\mathrm{B}$, biochar; $\mathrm{COP}$, compost from olive pomace; $\mathrm{CW}$, vermicompost from cattle manure; CD1, compost from $90 \%$ cattle anaerobic digestate with $10 \%$ wheat straw addition; CD2, compost from $79 \%$ cattle anaerobic digestate with $11 \%$ crop residues and $10 \%$ wheat straw addition),

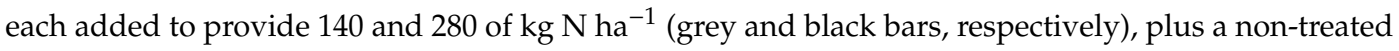
soil or control (NT, white bar). The graphs on the left refer to the first cut of the leaves (a,c,e) while on the right to the second cut $(\mathbf{b}, \mathbf{d}, \mathbf{f})$. Values are means $(n=4) \pm$ standard errors. Data presented in each graph were analyzed by two-way ANOVA followed by the Duncan test at $p \leq 0.05$. A, amendment; D, dose; ${ }^{*}, p \leq 0.05 ;{ }^{* *}, p \leq 0.01 ;{ }^{* * *}, p \leq 0.001 ;$ n.s., not significant. 
At the second cut, H, LA, and FW (Figure $2 \mathrm{~b}, \mathrm{~d}$, f, respectively) significantly differed among organic amendments $(p \leq 0.001)$. Except for H, LA, and FW also differed between the applied doses $(p \leq 0.05$ and $p \leq 0.01$ for LA and FW, respectively). As already reported for the first leaf cut, H, LA, and FW values were higher in CD2, CD1, and CW $\left(10.2 \mathrm{~cm}, 76.5 \mathrm{~cm}^{2}\right.$, and $4.3 \mathrm{~g}$, respectively, as the average of the three treatments) than COP and B. This latter was found to be not statistically different from the non-treated control (NT). LA and FW resulted generally higher when the plants were treated with the double dose of CD2, CD1, and CW $\left(84.4 \mathrm{~cm}^{2}\right.$ and $4.8 \mathrm{~g}$, respectively, as an average of the three treatments) compared to the single one.

\subsection{Total $\mathrm{N}$ and $\mathrm{NO}_{3}{ }^{-}$Leaf Content}

Total $\mathrm{N}$ content of Swiss chard leaves was significantly influenced by organic amendments $(p \leq 0.001)$, doses $(p \leq 0.001)$ as well as their interaction $(p \leq 0.001)$, both at the first and second cut, as shown in Figure $3 \mathrm{a}, \mathrm{b}$, respectively.
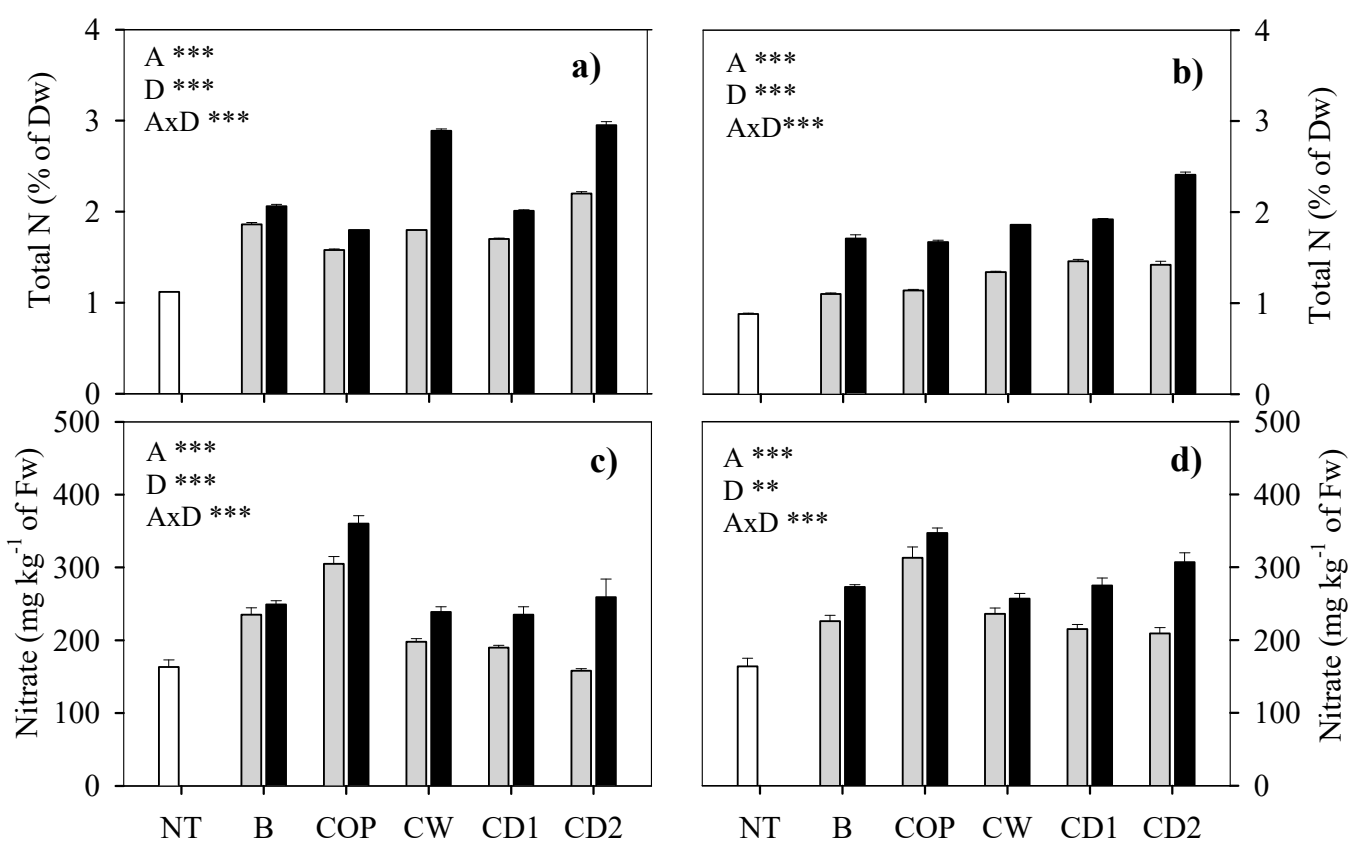

Figure 3. Total nitrogen $(\mathbf{a}, \mathbf{b})$ and nitrate content $(\mathbf{c}, \mathbf{d})$ of Swiss chard treated with different organic amendments (B, biochar; $\mathrm{COP}$, compost from olive pomace; $\mathrm{CW}$, vermicompost from cattle manure; CD1, compost from $90 \%$ cattle anaerobic digestate with $10 \%$ wheat straw addition; CD2, compost from $79 \%$ cattle anaerobic digestate with $11 \%$ crop residues and $10 \%$ wheat straw addition), each added to provide 140 and 280 of $\mathrm{kg} \mathrm{N} /$ ha, (grey and black bars, respectively), plus a non-treated soil or control (NT, white bar). The graphs on the left refer to the first leaf cut $(\mathbf{a}, \mathbf{c})$ while on the right to the second cut $(\mathbf{b}, \mathbf{d})$. Values are means $(\mathrm{n}=4) \pm$ standard errors. Data in each graph were analyzed by two-way ANOVA followed by Duncan test at $p \leq 0.05$. A, amendment; D, dose; ${ }^{* *}, p \leq 0.01 ;{ }^{* * *}, p \leq 0.001$.

At the first leaf cut (Figure 3a), the total $\mathrm{N}$ value was significantly higher in plants treated with $\mathrm{CD} 2(2.6 \% \pm 0.4 \% \mathrm{dw})$ than B $(2.0 \% \pm 0.1 \% \mathrm{dw}), \mathrm{CD} 1(1.9 \% \pm 0.2 \% \mathrm{dw}), \mathrm{COP}(1.7 \% \pm 0.1 \% \mathrm{dw})$ and NT $(1.1 \% \pm 0.1 \% \mathrm{dw})$. CD2 did not differ from CW $(2.3 \% \pm 0.5 \% \mathrm{dw})$. On average, significantly higher values of total $\mathrm{N}$ were registered when the soil was treated with the double dose of amendments $(2.3 \% \pm 0.2 \% \mathrm{dw})$ than the single one $(1.8 \% \pm 0.1 \% \mathrm{dw})$. The highest total $\mathrm{N}$ content in leaf tissues was equal to $2.9 \% \pm 0.1 \% \mathrm{dw}$ for plants treated with CD2 at double dose, with an increase of $163 \%$ compared with NT. At the second cut of the leaves (Figure 3b), total N content was significantly higher in plants treated with amendments from animal wastes $(1.7 \% \pm 0.2 \% \mathrm{dw}$, as average of CD2, CD1 and $\mathrm{CW}$ ) than non-treated soil (NT $=0.9 \% \pm 0.1 \% \mathrm{dw}$ ), followed by compost from olive pomace 
$(\mathrm{COP}=1.4 \% \pm 0.3 \% \mathrm{dw})$ and biochar $(\mathrm{B}=1.4 \% \pm 0.2 \% \mathrm{dw})$ that did not differ between each other. Again, the soil addition with the double dose of organic amendments significantly increased nitrogen leaf content than the single one $(1.9 \% \pm 0.1 \% \mathrm{dw}$ vs. $1.3 \% \pm 0.1 \% \mathrm{dw})$. Total $\mathrm{N}$ reached the highest value $(2.4 \% \pm 0.1 \% \mathrm{dw})$ in plants treated with double dose of CD2, showing an increase of $176 \%$ in comparison with NT.

Figure $3 \mathrm{c}, \mathrm{d}$ report the $\mathrm{NO}_{3}{ }^{-}$content measured on Swiss chard leaves at the first and second cut, respectively. $\mathrm{NO}_{3}{ }^{-}$content was always affected by organic amendments $(p \leq 0.001)$ and doses $(p \leq 0.001)$, as well as their interaction $(p \leq 0.001)$. At the first cut, plants treated with compost from olive pomace (COP) showed significantly higher $\mathrm{NO}_{3}{ }^{-}$content $\left(333.2 \pm 12.2 \mathrm{mg} \mathrm{kg}^{-1} \mathrm{Fw}\right)$ than the other amendments $\left(\mathrm{B}=242.5 \pm 5.1 ; \mathrm{CW}=217.7 \pm 8.5 ; \mathrm{CD} 1=212.7 \pm 9.7 ; \mathrm{CD} 2=208.5 \pm 21.6 \mathrm{mg} \mathrm{kg}^{-1} \mathrm{Fw}\right)$ and non-treated control $\left(\mathrm{NT}=163.1 \pm 8.4 \mathrm{mg} \mathrm{kg}^{-1} \mathrm{Fw}\right)$. Soil addition with the double dose of amendments always resulted in higher leaf $\mathrm{NO}_{3}{ }^{-}$content (on average, $268.6 \pm 11.8 \mathrm{mg} \mathrm{kg}^{-1} \mathrm{Fw}$ ) than the single one (on average, $217.2 \pm 11.8 \mathrm{mg} \mathrm{kg}^{-1} \mathrm{Fw}$ ). The highest $\mathrm{NO}_{3}{ }^{-}$leaf content, equal to $360.9 \pm 10.3 \mathrm{mg} \mathrm{kg}^{-1} \mathrm{Fw}$, was observed in plants treated with the double dose of COP. A similar trend of $\mathrm{NO}_{3}{ }^{-}$leaf content was observed at the second leaf cut. $\mathrm{NO}_{3}{ }^{-}$was higher in plants treated with COP $\left(330.7 \pm 9.7 \mathrm{mg} \mathrm{kg}^{-1} \mathrm{FW}\right)$ than the other amendments $(\mathrm{B}=249.1 \pm 9.4 ; \mathrm{CW}=246.4 \pm 5.9 ; \mathrm{CD} 1=244.9 \pm 12.5$; $\left.\mathrm{CD} 2=258.3 \pm 19.4 \mathrm{mg} \mathrm{kg}^{-1} \mathrm{Fw}\right)$ and non-treated control (NT $\left.163.8 \pm 9.7 \mathrm{mg} \mathrm{kg}^{-1} \mathrm{Fw}\right)$. The average value of $\mathrm{NO}_{3}{ }^{-}$content was significantly higher when the plants were treated with the double amendment dose $\left(291.9 \pm 8.0 \mathrm{mg} \mathrm{kg}^{-1} \mathrm{Fw}\right)$ than the single one $\left(239.9 \pm 9.3 \mathrm{mg} \mathrm{kg}^{-1} \mathrm{Fw}\right)$. The highest $\mathrm{NO}_{3}{ }^{-}$content was detected in plants treated with COP at double dose $\left(347.6 \pm 6.2 \mathrm{mg} \mathrm{kg}^{-1} \mathrm{Fw}\right)$.

\subsection{Pigment Leaf Content}

The leaf CA, CHL a, CHL b, and total CHL content (Figure 4) measured at the first cut of Swiss chard leaves resulted statistically different only among the amendments $(p \leq 0.05)$. A significantly

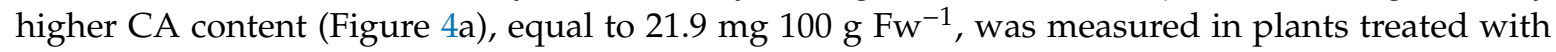
compost from animal wastes (CD2). Values of CA ranging from 17.3 to $19.2 \mathrm{mg} 100 \mathrm{~g} \mathrm{Fw}^{-1} \mathrm{were}^{-}$ observed in plants treated with compost from olive pomace (COP) and the two amendments from animal wastes (CW and CD1). The lowest CA content was equal to $14.7 \mathrm{mg} 100 \mathrm{~g} \mathrm{Fw}^{-1}$, as measured in plants treated with biochar (B) that did not differ from non-treated control (NT). As CA, also the leaf CHL a content (Figure 4b) was significantly higher in plants treated with CD2 (91.3 mg $\left.100 \mathrm{~g} \mathrm{Fw}^{-1}\right)$,

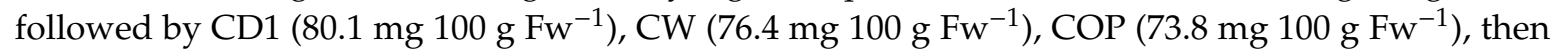
$\mathrm{B}$ and NT that showed very low values (57.8 and $55.8 \mathrm{mg} 100 \mathrm{~g} \mathrm{Fw}^{-1}$, respectively). A similar trend was observed for CHL b (Figure 4c) and total CHL (Figure 4d). Indeed, the highest values of CHL b

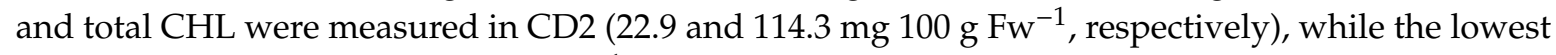
values in B (14.0 and $71.0 \mathrm{mg} 100 \mathrm{~g} \mathrm{Fw}^{-1}$, respectively) that did not differed from NT (14.5 and $70.4 \mathrm{mg}$ $100 \mathrm{~g} \mathrm{Fw}^{-1}$, respectively). As observed for the leaf CA, CHL a, CHL b, and total CHL content, also the leaf SPAD values (Table 3), were significantly affected only by the organic amendment added to the soil ( $p \leq 0.01)$. At the first leaf cut, plants treated with CW showed the highest chlorophyll content (SPAD reading), with SPAD leaf equal to 40.9 and SPAD $_{\text {plant }}$ to 31.8. At the second cut of Swiss chard

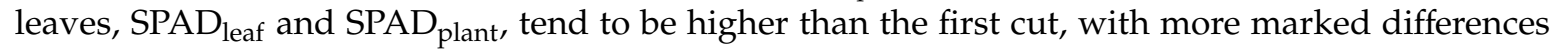
among the treatments, especially between plants treated with amendments from animal wastes $(C W$, CD1, and CD2) and plants treated with the other two amendments, i.e., compost from olive pomace (COP) and biochar (B), that did not differ from the non-treated control (NT). 

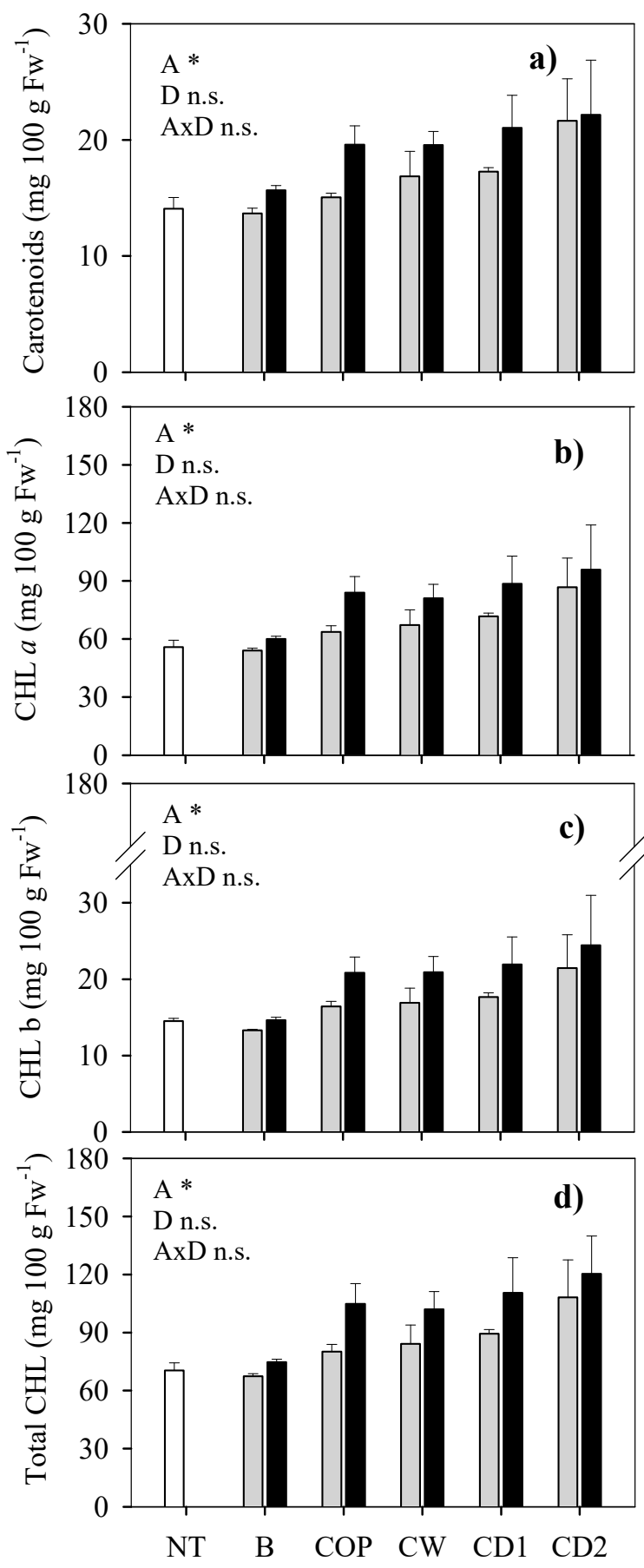

Figure 4. Carotenoids (a), chlorophyll a (b), chlorophyll b (c), and total chlorophyll (d) contents in Swiss chard treated with different organic amendments (B, biochar; COP, compost from olive pomace; CW, vermicompost from cattle manure; CD1, compost from $90 \%$ cattle anaerobic digestate with $10 \%$ wheat straw addition; CD2, compost from $79 \%$ cattle anaerobic digestate with $11 \%$ crop residues and $10 \%$ wheat straw addition), each added to provide 140 and $280 \mathrm{of} \mathrm{kg} \mathrm{N} / \mathrm{ha}$, (grey and black bars, respectively), plus a non-treated soil or control (NT, white bar). Values are means $(n=4) \pm$ standard errors. Data in each graph were analyzed by two-way ANOVA followed by a Duncan test at $p \leq 0.05$. A, amendment; D, dose; ${ }^{*}, p \leq 0.05 ;$ n.s., not significant. 
Table 3. SPAD meter values relatively to the youngest fully expanded leaf ( $\left.S P A D_{\text {leaf }}\right)$ and the whole plant $\left(\mathrm{SPAD}_{\text {plant }}\right)$, at the first and second cut of Swiss chard leaves grown on soil mixed with different organic amendments, each added in two doses to, respectively, provide 140 and $280 \mathrm{~kg} \mathrm{~N} \mathrm{ha}^{-1}$.

\begin{tabular}{|c|c|c|c|c|c|}
\hline \multirow{2}{*}{ Amendment } & \multirow{2}{*}{ Dose (Kg N ha-1) } & \multicolumn{2}{|c|}{ First Leaf Cut } & \multicolumn{2}{|c|}{ Second Leaf Cut } \\
\hline & & SPAD $_{\text {leaf }}$ & SPAD $_{\text {plant }}$ & SPAD $_{\text {leaf }}$ & SPAD plant \\
\hline \multirow{2}{*}{ NT } & - & $32.8 \pm 2.9$ & $25.9 \pm 2.6$ & $36.1 \pm 1.9$ & $32.8 \pm 2.0$ \\
\hline & average & $32.8^{B}$ & $25.9^{B}$ & $36.0^{C}$ & $32.8^{C}$ \\
\hline \multirow{3}{*}{ B } & 140 & $35.3 \pm 1.9$ & $27.1 \pm 0.8$ & $36.7 \pm 1.8$ & $34.1 \pm 1.4$ \\
\hline & 280 & $32.9 \pm 2.4$ & $26.6 \pm 1.5$ & $35.3 \pm 1.1$ & $32.1 \pm 0.9$ \\
\hline & average & $34.1^{A B}$ & $26.8^{A B}$ & $36.0^{C}$ & $33.0^{C}$ \\
\hline \multirow{3}{*}{ COP } & 140 & $39.7 \pm 2.3$ & $28.7 \pm 2.1$ & $35.0 \pm 0.8$ & $31.5 \pm 0.7$ \\
\hline & 180 & $40.0 \pm 2.7$ & $29.4 \pm 2.1$ & $39.3 \pm 1.6$ & $35.6 \pm 1.0$ \\
\hline & average & $39.8^{A B}$ & $29.0^{A B}$ & $37.1^{B C}$ & $33.5^{B C}$ \\
\hline \multirow{3}{*}{ CW } & 140 & $42.4 \pm 1.6$ & $32.9 \pm 2.0$ & $42.0 \pm 1.1$ & $36.1 \pm 1.4$ \\
\hline & 280 & $39.4 \pm 2.7$ & $30.6 \pm 0.8$ & $39.8 \pm 0.9$ & $35.9 \pm 1.1$ \\
\hline & average & $40.9^{A}$ & $31.8^{A}$ & $40.9^{A B}$ & $36.0^{A B}$ \\
\hline \multirow{3}{*}{ CD1 } & 140 & $36.9 \pm 0.7$ & $30.7 \pm 1.1$ & $41.0 \pm 1.2$ & $36.8 \pm 0.8$ \\
\hline & 280 & $41.2 \pm 4.3$ & $30.6 \pm 1.7$ & $43.0 \pm 1.2$ & $39.5 \pm 1.2$ \\
\hline & average & $39.1^{A B}$ & $30.6^{A B}$ & $42.0^{A}$ & $38.2^{A}$ \\
\hline \multirow{3}{*}{$\mathrm{CD} 2$} & 140 & $36.7 \pm 0.7$ & $26.6 \pm 0.6$ & $39.9 \pm 1.6$ & $35.4 \pm 0.8$ \\
\hline & 280 & $42.3 \pm 2.7$ & $29.5 \pm 2.5$ & $39.6 \pm 1.9$ & $36.1 \pm 0.6$ \\
\hline & average & $39.5^{A B}$ & $28.0^{A B}$ & $39.8^{A B}$ & $35.8^{A B}$ \\
\hline
\end{tabular}

NT, non-treated soil or control; B, biochar; COP, compost from olive pomace; CW, vermicompost from cattle manure; CD1, compost from $90 \%$ cattle anaerobic digestate with $10 \%$ wheat straw addition; CD2, compost from $79 \%$ cattle anaerobic digestate with $11 \%$ crop residues and $10 \%$ wheat straw addition. Values are means $(n=4) \pm$ standard errors. In each column, the average values of the two amendment doses followed by the same letters are not significantly different at $p \leq 0.05$, according to the Duncan test.

\section{Discussion}

\subsection{Influence of Organic Amendments on Plant Growth}

According to the obtained results, Swiss chard growth was effectively enhanced by adding organic amendments to the soil, particularly the amendments deriving from animal wastes as cattle manure and cattle anaerobic digestate (CW, CD1, and CD2, respectively). Similar results were obtained by Doan et al. [43], who reported increased maize growth and yield after soil amendment with vermicompost and compost obtained from buffalo manure.

Swiss chard responded positively to CW, CD1, and CD2, likely due to a greater release of mineral nutrients, mostly of nitrogen, in the treated soil. Although the higher salinity of amendments from animal wastes (EC $=2.7,4.3$ and $2.0 \mathrm{dS} \mathrm{m}^{-1}$, respectively for $\mathrm{CW}, \mathrm{CD} 1$, and $\mathrm{CD} 2$ ) than that of the receiving soil $\left(\mathrm{EC}=0.4 \mathrm{dS} \mathrm{m}^{-1}\right)$, a higher Swiss chard growth was still observed, due to the tolerance of this species to saline conditions [27].

Referring to results obtained from plants treated with olive pomace compost (COP), lower plant height, leaf area, and fresh weight values were observed. This effect was likely due to the higher $\mathrm{C} / \mathrm{N}$ ratio of $\mathrm{COP}$ than the amendments deriving from animal wastes $(\mathrm{C} / \mathrm{N}=22,12,10$, and 10 for $\mathrm{COP}, \mathrm{CW}$, $\mathrm{CD} 1$, and $\mathrm{CD} 2$, respectively). The higher $\mathrm{C} / \mathrm{N}$ ratio likely resulted in a higher $\mathrm{N}$ immobilization in soil added with COP than CW, CD1, and CD2 that increased the competition for nitrogen in plants and soil microorganisms, determining a slower $\mathrm{N}$ release and a lower $\mathrm{N}$ availability for plant uptake. In this regard, Garcia-Ruiz et al. [44] reported the effects of $\mathrm{N}$ immobilization during the short-term (3-12 months) decomposition of an olive pomace compost, also evidenced by reduced nitrate lost from the soil. On the contrary, in the long term (15 years), the authors observed an increase of total $\mathrm{N}$ amount and $\mathrm{N}$ easily mineralized pool in the soil. Morra et al. [45] found that the higher the quantity of olive pomace compost applied to the soil, the slower the release of $\mathrm{NO}_{3}{ }^{-}-\mathrm{N}$ for crop needs. 
The application of biochar did not show any positive effect on the productive response of Swiss chard plants. As reported in the literature, the effects of biochar addition to cultivated soil on crop growth are highly variable [46] and not always consistent [47], due to the different biochar feedstock types, pyrolysis conditions, biochar structure and composition [48-51], soil properties [52,53], and tested crop [54]. Gravel et al. [55] reported that the amendment of potting soil with biochar had no significant effect on shoot growth of sweet pepper, geranium, and basil; while increased coriander shoot weight and decreased the weight of lettuce plants. In a net-house experiment carried out to assess the impacts on plant growth of different biochar types in comparison with their biomass sources, Khan et al. [56] observed a better growth of the kalmi plant (Ipomea aquatica) under cow dung biomass treatment than cow dung biochar. Under the other treatments with two biochar types, respectively, from poultry manure and sludge, plant growth was lower than the non-treated control. Furthermore, the negative effects of biochar on horticultural crop growth were reported when biochar was made from poultry litter [57]. Shoot length and fresh/dry masses of red lettuce plants grown in a rice husk biochar substrate were decreased by $49 \%$ compared to the perlite substrate [58]. Decreased growth and nutrient uptake imbalance were observed in lettuce and corn plants after the application of freshly prepared biochar into the soil [59]. Atkinson et al. [60] observed that the usually high $\mathrm{C} / \mathrm{N}$ ratios of biochar could lead to a higher $\mathrm{N}$ immobilization and eventually to $\mathrm{N}$ deficiencies in plants. In this regard, Clough and Condron [61] reported $\mathrm{N}$ immobilization in biochar amended soils; Novak et al. [62], in vitro experiments, reported a $\mathrm{NO}_{3}{ }^{-}-\mathrm{N}$ immobilization between $40 \%$ and $70 \%$ due to biochar application. Limiting $\mathrm{N}$ content by biochar application in soils due to the high $\mathrm{C} / \mathrm{N}$ ratio, it might reduce crop productivity temporarily [63]. Biochar used in our experiment had a high $\mathrm{C} / \mathrm{N}$ ratio (see Table 2), and our results could be likely due to a more limited supply of nitrogen for plant uptake. The negative impact of biochar on $\mathrm{N}$ availability for Swiss chard growth resulted even more critically, considering the short growth cycle of the plants and the biochar benefits that may be achieved over time in comparison with the composts.

\subsection{Influence of Organic Amendments on Nitrogen, Nitrate and Pigment Leaf Content}

Still considering the obtained results, total $\mathrm{N}$ leaf content was higher in Swiss chard plants growing on soil treated with amendments from animal wastes, particularly when the double dose (280 $\mathrm{kg} \mathrm{ha}^{-1}$ ) was added, than the compost from olive pomace and biochar. Hernandez et al. [64], in a greenhouse experiment aimed at evaluating the effect on lettuce of compost and vermicompost from cattle manure with an estimated $\mathrm{N}$ contribution to the soil of $278 \mathrm{~kg} \mathrm{ha}^{-1}$, observed a leaf $\mathrm{N}$ content of $1.4 \%$ and $1.6 \% \mathrm{dw}$ in vermicompost and compost, respectively. The authors reported a lower nitrogen leaf content than our study if considering the double dose of amendment addition to the soil. Such differences will be likely due to the dynamic of nutrient release in the soil after incorporating organic fertilizers. The nutrient release and the consequent nutrient availability for plant uptake in the soil are not only related to the total amount of mineral elements contained in the amendment but largely depend on the amendment properties [65]. The stability of organic matter, maturity, and the physico-chemical characteristics are factors influencing the $\mathrm{N}$ availability in composts. The $\mathrm{N}$ dynamic in the soil after adding organic amendments can also be affected by environmental conditions (soil type and climate), which make difficult the comparison of different experiments [66-68]. Moreover, the nitrogen content of the Swiss chard is strongly affected by fertilization [1,6]. In our study, no mineral fertilization was applied, therefore, the increases in $\mathrm{N}$ content observed in plants growing in the amended soils relative to the non-treated control indicate a certain release of $\mathrm{N}$ from the organic amendments, net of possible $\mathrm{N}$ immobilization and volatile $\mathrm{N}$ losses. Although organic amendments were added to the soil in two doses in order to, respectively, provide 140 and $280 \mathrm{~kg} \mathrm{~N} \mathrm{ha}^{-1}$, Swiss chard plants took up the amount of $\mathrm{N}$ that actually became available for plant growth. This may be the reason for the low nitrogen content observed in our study in comparison with the results found by other authors. For instance, Echer et al. [69] found a Swiss chard nitrogen content varying from 36 to $43 \mathrm{~g} \mathrm{~kg}^{-1}$ by increasing the mineral nitrogen fertilization dose from 0 to $160 \mathrm{~kg} \mathrm{ha}^{-1}$. 
Referring to our results about leaf $\mathrm{NO}_{3}{ }^{-}$content, it is worth to underline that, among leafy vegetables (i.e., rocket, spinach, lettuce, celery, and parsley), Swiss chard is known as one of the most prominent nitrate-accumulating species [6] (Santamaria, 2006). $\mathrm{NO}_{3}{ }^{-}$content of Swiss chard leaves evaluated in our experiment was in the range reported by EFSA [70] and an updated review by Colla et al. [71]. Moreover, it was well below the $\mathrm{NO}_{3}{ }^{-}$thresholds established by the European Commission regulations $\mathrm{N}^{\circ}$ 1881/2006 and 1258/2011 for fresh spinach (3500 $\mathrm{mg} \mathrm{kg}^{-1} \mathrm{Fw}$ ); preserved, deep-frozen or frozen spinach (2000 $\left.\mathrm{mg} \mathrm{kg}^{-1} \mathrm{Fw}\right)$; fresh lettuce (3000-5000 $\left.\mathrm{mg} \mathrm{kg}^{-1} \mathrm{Fw}\right)$; Iceberg type lettuce (2000-2500 $\left.\mathrm{mg} \mathrm{kg}^{-1} \mathrm{Fw}\right)$; salad and wild rocket. (6000-7000 $\mathrm{mg} \mathrm{kg}^{-1} \mathrm{Fw}$ ).

Nitrate content in vegetables depends on the crop cultivation system adopted, as showed by Herencia et al. [72]. The authors reported a lower nitrate content in organic (from 546 to $1274 \mathrm{mg} \mathrm{kg}^{-1} \mathrm{Fw}$ ) than mineral fertilized (from 780 to $2113 \mathrm{mg} \mathrm{kg}^{-1} \mathrm{Fw}$ ) Swiss chard. Matallana González et al. [73] in samples of Swiss chard collected directly from an organic farm in Spain found values of nitrate content ( $\left.2630.4 \mathrm{mg} \mathrm{kg}^{-1} \mathrm{Fw}\right)$ near or higher than the ones purchased from organic food stores $\left(2595 \mathrm{mg} \mathrm{kg}^{-1} \mathrm{Fw}\right)$. Lower nitrate values (in the range of $546-1274 \mathrm{mg} \mathrm{kg}^{-1} \mathrm{Fw}$ ) were observed by Bosch Bosch et al. [74] in organic Swiss chard. Our results are very similar to those found by Raigon et al. [75] who reported for organically cultivated Swiss chard a nitrate content below $400 \mathrm{mg} \mathrm{kg}^{-1} \mathrm{Fw}$.

Despite the lower total $\mathrm{N}$ content, leaves of Swiss chard plants treated with compost from olive pomace (COP) showed a higher $\mathrm{NO}_{3}{ }^{-}$content than the other organic amendments, both applying the single and the double dose. This may have been due to the higher $\mathrm{NO}_{3}{ }^{-}-\mathrm{N}$ availability than $\mathrm{NH}_{4}{ }^{+}-\mathrm{N}$ from COP, likely occurred in the soil treated with such compost. This condition may have led to higher nitrate accumulation in the leaves of COP treated plants. Indeed, as previously reported by Barcelos et al. [76] and Conesa et al. [77], spinach (like Swiss chard, spinach is a very high accumulator vegetable of $\mathrm{NO}_{3}^{-}$) accumulated more nitrate when grown with nutrient solutions containing high $\mathrm{NO}_{3}{ }^{-}-\mathrm{N}: \mathrm{NH}_{4}{ }^{+}-\mathrm{N}$ ratio. In addition, the high $\mathrm{NO}_{3}{ }^{-}$content observed in plants treated with COP could also be related to lower nitrogen assimilation (conversion of mineral nitrogen in organic nitrogen) that likely occurred in the course of plant growth cycles. It is known that the nitrate assimilation pathway starts with nitrate uptake followed by nitrate reduction resulting in ammonium, which is fixed into the amino acids glutamine and glutamate in most plants [78]. The hypothesis that in COP treated plants, the nitrate uptake exceeded nitrate reduction could also be supported by their lower height, leaf area, and leaf fresh weight than the plants treated with the other organic amendments (Figure 2a,c,e, respectively). A critical examination of the factors that can affect nitrate accumulation in a wide range of horticultural crops is reported in Colla et al. [71].

The leaf chlorophyll readings performed in all the experimental treatments were within the range reported by other authors $[76,77,79]$. The higher leaf pigment content (carotenoids and chlorophyll) observed in plants treated with amendments from animal wastes (CW, CD1, and CD2) than compost from olive pomace (COP) and biochar (B) were likely due to an improved plant nutritional status. More specifically, this result may be due to the higher availability of nitrogen, which is known to be an integral part of chlorophyll molecules (in addition to amino acids, nucleic acids, phosphatides, alkaloids, enzymes, hormones, and vitamins) [80], which the Swiss chard plants experienced in the abovementioned treatments.

\section{Conclusions}

Under the adopted experimental conditions (pot cultivation and short crop growing cycle), Swiss chard responded positively to the application of organic amendments. Particularly when amendments from animal wastes (vermicompost from cattle manure and composts from cattle anaerobic digestate) were added to the soil, significant increases of plant growth parameters and pigment leaf contents were observed, indicating suitable soil growth conditions for ensuring plant yield and quality. Moreover, the higher nitrogen leaf content of Swiss chard growing in soil treated with amendments from animal wastes suggested the adequate fertilizing value of the tested products. 
For all the considered organic amendments, the double dose $\left(280 \mathrm{~kg} \mathrm{~N} \mathrm{ha}^{-1}\right)$ increased the growth parameters compared to the single dose $\left(140 \mathrm{~kg} \mathrm{~N} \mathrm{ha}^{-1}\right)$ and the nitrate content of the leaves was always well below the threshold for $\mathrm{NO}_{3}{ }^{-}$concentration in other leafy vegetables (spinach, lettuce, and rocket), as established by the European Union to avoid harmful effects on human health of raw vegetable consumption. Unlike the amendments obtained from animal wastes, biochar from vine pruning did not lead to positive or negative effects on growth and pigment chlorophyll content of Swiss chard, with results equal to those detected on non-treated plants.

The conclusion to be drawn suggests that organic amendments applied to the soil can contribute to improving the quantitative and qualitative traits of Swiss chard. However, the different response of plants to biochar, vermicompost, and composts utilized in the experiment suggests that further experiments, as well as field-scale trials, are needed to better understand the effects of type and dose of amendment able to improve the production of fresh-cut vegetables characterized by short-growing cycle such as Swiss chard.

Author Contributions: Conceptualization, A.L. and A.R.R.; methodology, A.L. and A.R.R.; validation, A.L. and A.R.R.; formal analysis, A.L., A.R.R., and V.T.; investigation, A.L. and A.R.R.; resources, A.L. and A.R.R.; data curation, A.L. A.R.R., and V.T.; writing—original draft preparation, A.L.; writing-review and editing, A.L. and A.R.R.; visualization, A.L..; supervision, A.L. and A.R.R.; project administration, A.R.R.; funding acquisition, A.R.R. All authors have read and agreed to the published version of the manuscript.

Funding: This research was carried out in the framework of the project "Smart Basilicata", which was approved by the Italian Ministry of Education, University and Research (Notice MIUR n.84/2012, PON 2007-2013 of 2 March 2012) and was funded by the Cohesion Fund 2007-2013 of the Basilicata Regional Authority.

Acknowledgments: The authors are grateful to Susanna De Maria, Giuseppe Mercurio and Antonio Pisani for the technical assistance in the greenhouse experiment and the laboratory analyses.

Conflicts of Interest: The authors declare no conflict of interest.

\section{References}

1. Ivanović, L.; Milašević, I.; Topalović, A.; Đurović, D.; Mugoša, B.; Knežević, M.; Vrvić, M. Nutritional and phytochemical content of Swiss chard from Montenegro, under different fertilization and irrigation treatments. Brit. Food J. 2019, 121, 411-425. [CrossRef]

2. Miceli, A.; Miceli, C. Effect of nitrogen fertilization on the quality of Swiss chard at harvest and during storage as minimally processed produce. J. Food Qual. 2014, 37, 125-134. [CrossRef]

3. Ninfali, P.; Angelino, D. Nutritional and functional potential of Beta vulgaris cicla and rubra. Fitoterapia 2013, 89, 188-199. [CrossRef] [PubMed]

4. Pyo, Y.H.; Lee, T.C.; Logendra, L.; Rosen, R.T. Antioxidant activity and phenolic compounds of Swiss chard (Beta vulgaris subspecies cycla) extracts. Food Chem. 2004, 85, 19-26. [CrossRef]

5. Santamaria, P.; Elia, A.; Serio, F.; Todaro, E. A survey of nitrate and oxalate content in fresh vegetables. J. Sci. Food Agric. 1999, 79, 1882-1888. [CrossRef]

6. Santamaria, P. Nitrate in vegetables: Toxicity, content, intake and EC regulation. J. Sci. Food Agric. 2006, 86, 10-17. [CrossRef]

7. Pokluda, R.; Kuben, J. Comparison of selected Swiss chard (Beta vulgaris ssp. cicla L.) varieties. Hort. Sci. 2002, 29, 114-118.

8. Kolota, E.; Adamczewska-Sowińska, K.; Czerniak, K. Yield and nutritional value of Swiss Chard Grown for Summer and Autumn Harvest. J. Agric. Sci. 2010, 2, 120-124. [CrossRef]

9. Libutti, A.; Monteleone, M. Soil vs. groundwater: The quality dilemma. Managing nitrogen leaching and salinity control under irrigated agriculture in Mediterranean conditions Agric. Water Manag. 2017, 186, 40-50.

10. Dzida, K.; Pitura, K. The influence of varied nitrogen fertilization on yield and chemical composition of Swiss chard (Beta vulgaris L. var. cicla L.). Acta Sci. Pol.-Hortorum 2008, 7, 15-24.

11. Engelbrecht, G.M.; Ceronio, G.M.; Motseki, P.C. Effect of nitrogen levels and sources on production of Swiss Chard (Beta vulgaris var. cicla). S. Afr. J. Plant Soil 2010, 27, 229-234. [CrossRef]

12. Razgallah, N.; Chikh-Rouhou, H.; Boughattas, I.; M'hamdi, M. Nitrates contents in some vegetables in Tunisia. Arch. Agron. Soil Sci. 2016, 62, 473-483. [CrossRef] 
13. Martínez-Blanco, J.; Lazcano, C.; Christensen, T.H.; Muñoz, P.; Rieradevall, J.; Møller, J.; Antón, A.; Boldrin, A. Compost benefits for agriculture evaluated by life cycle assessment: A review. Agron. Sustain. Dev. 2013, 33, 721-732. [CrossRef]

14. Nair, V.D.; Nair, P.K.R.; Dari, B.; Freitas, A.M.; Chatterjee, N.; Pinheiro, F.M. Biochar in the Agroecosystem-Climate-Change-Sustainability Nexus. Front. Plant Sci. 2017, 8, 1-9. [CrossRef]

15. Demiraj, E.; Libutti, A.; Malltezi, J.; Rroço, E.; Brahushi, F.; Monteleone, M.; Sulçe, S. Effect of organic amendments on nitrate leaching mitigation in a sandy loam soil of Shkodra district, Albania. Ital. J. Agron. 2018, 13, 1136. [CrossRef]

16. Libutti, A.; Mucci, M.; Francavilla, M.; Monteleone, M. Effect of biochar amendment on nitrate retention in a silty clay loam soil. Ital. J. Agron. 2016, 11, 273-276. [CrossRef]

17. Gobbi, V.; Bonato, S.; Nicoletto, C.; Zanin, G. Spent mushroom substrate as organic fertilizer: Vegetable organic trials. Acta Hortic. 2016, 1146, 49-56. [CrossRef]

18. Lehmann, J. Bio-energy in the black. Front. Ecol. Environ. 2007, 5, 381-387. [CrossRef]

19. Zabaniotou, A.; Rovas, D.; Libutti, A.; Monteleone, M. Boosting circular economy and closing the loop in agriculture: Case study of a small-scale pyrolysis-biochar based system integrated in an olive farm in simbiosi with an olive mill. Environ. Dev. 2015, 14, 22-36. [CrossRef]

20. Monlau, F.; Francavilla, M.; Sambusiti, C.; Antoniou, N.; Solhy, A.; Libutti, A.; Zabaniotou, A.; Barakat, A.; Monteleone, M. Toward a functional integration of anaerobic digestion and pyrolysis for a sustainable resource management. Comparison between solid-digestate and its derived pyrochar as soil amendment. Appl. Energy 2016, 169, 652-662. [CrossRef]

21. Zabaniotou, A.; Rovas, D.; Delivand, M.K.; Francavilla, M.; Libutti, A.; Cammerino, A.R.B.; Monteleone, M. Conceptual vision of bioenergy sector development in Mediterranean regions based on decentralized thermochemical systems. Sustain. Energy Technol. Assess. 2017, 23, 33-47. [CrossRef]

22. Libutti, A.; Cammerino, A.R.B.; Francavilla, M.; Massimo, M. Soil Amendment with Biochar Affects Water Drainage and Nutrient Losses by Leaching: Experimental Evidence under Field-Grown Conditions. Agronomy 2019, 9, 758. [CrossRef]

23. Urra, J.; Alkorta, I.; Garbisu, C. Potential benefits and risks for soil health derived from the use of organic amendments in agriculture. Agronomy 2019, 9, 542. [CrossRef]

24. Subedi, R.; Bertora, C.; Zavattaro, L.; Grignani, C. Crop response to soils amended with biochar: Expected benefits and unintended, risks. Ital. J. Agron 2017, 12, 161-173. [CrossRef]

25. Paredes, C.; Cegarra, J.; Bernal, M.P.; Roig, A. Influence of olive mill wastewater in composting and impact of the compost on a Swiss chard crop and soil properties. Environ. Int. 2005, 31, 305-312. [CrossRef]

26. Abbey, L.; Young, C.; Teitel-Payne, R.; Howe, K. Evaluation of proportions of vermicompost and coir in a medium for container-grown Swiss chard. Int. J. Veg. Sci. 2012, 18, 109-120. [CrossRef]

27. Smith, D.C.; Beharee, V.; Hughes, J.C. The effects of compost produced by a simple composting procedure on the yields of Swiss chard (Beta vulgaris L. var. flavescens) and common bean (Phaseolus vulgaris L. var. nanus). Sci. Hortic. 2001, 91, 393-406.

28. Trupiano, D.; Cocozza, C.; Baronti, S.; Amendola, C.; Vaccari, P.F.; Lustrato, G.; Di Lonardo, S.; Fantasma, F.; Tognetti, R.; Scippa, G.S. The Effects of Biochar and Its Combination with Compost on Lettuce (Lactuca sativa L.) Growth, Soil Properties, and Soil Microbial Activity and Abundance. Int. J. Agron. 2017, 2017, 3158207. [CrossRef]

29. Liu, B.; Cai, Z.; Zhang, Y.; Liu, G.; Luo, X.; Zheng, H. Comparison of efficacies of peanut shell biochar and biochar-based compost on two leafy vegetable productivity in an infertile land. Chemosphere 2019, 224, 151-161. [CrossRef]

30. Carter, S.; Shackley, S.; Sohi, S.; Suy, T.B.; Haefele, S. The Impact of Biochar Application on Soil Properties and Plant Growth of Pot Grown Lettuce (Lactuca sativa) and Cabbage (Brassica chinensis). Agronomy 2013, 3, 404-418. [CrossRef]

31. Olsen, S.R.; Cole, C.V.; Watanabe, F.S.; Dean, L.A. Estimation of Available Phosphorus in Soil by Extraction with Sodium Bicarbonate; USDA Circular 939; USDA: Washington, DC, USA, 1954; pp. 1-19.

32. Walkley, A.; Black, I.A. An examination of the Degtjareff method fordetermining soil organic matter and a proposed modification of the chromicacid titration method. Soil Sci. 1934, 37, 29-38. [CrossRef]

33. Bremner, J.M. Nitrogen-total. In Methods of Soil Analysis Part 3-Chemical Methods; SSSA Book Ser. No. 5; Sparks, D.L., Page, A.L., Johnston, C.T., Summ, M.E., Eds.; SSSA: Madison, WI, USA, 1996; pp. 1058-1121. 
34. Keeney, D.R.; Nelson, D.W. Nitrogen Inorganic Forms. In Methods of Soil Analysis Part 2, 2nd ed.; Page, A.L., Miller, R.H., Keeney, D.R., Eds.; American Society of Agronomy and Soil Science Society of America Publisher: Madison, WI, USA, 1982; pp. 643-698.

35. Chan, K.Y.; Xu, K. Biochar: Nutrient properties and their enhancement. In Biochar for Environmental Management. Science and Technology; Lehmann, J., Joseph, S., Eds.; Earthscan: London, UK, 2009; pp. 67-84.

36. EBC. European Biochar Certificate Guidelines for a Sustainable Production of Biochar; European Biochar Certificate (EBC): Arbaz, Switzerland, 2012.

37. IBI. International Bichar Inititative, Standardized Product Definition and Product Testing Guidelines for Biochar that is Used in Soil; IBI-STD-2.0; IBI: Toronto, ON, Canada, 2014.

38. Cheng, C.H.; Lehmann, J.; Engelhard, M.H. Natural oxidation of black carbon in soils: Changes in molecular form and surface charge along a climosequence. Geochim. Cosmochim. Acta 2008, 72, 1598-1610. [CrossRef]

39. Schimmelpfennig, S.; Glaser, B. One step forward toward characterization: Some important material properties to distinguish biochars. J. Environ. Qual. 2012, 41, 1001-1013. [CrossRef] [PubMed]

40. Cataldo, D.A.; Maroon, M.; Schrader, L.E.; Youngs, V.L. Rapid Colorimetric Determination of Nitrate in Plant-Tissue by Nitration of Salicylic-Acid. Commun. Soil Sci. Plan Anal. 1975, 6, 71-80. [CrossRef]

41. Porra, R.J.; Thompson, W.A.; Kriedemann, P.E. Determination of accurate extinction coefficients and simultaneous equations for assaying chlorophylls a and $b$ extracted with four different solvents: Verification of the concentration of chlorophyll standards by atomic absorption spectrometry. Biochim. Biophys. Acta 1989, 975, 384-394. [CrossRef]

42. Wellburn, A.R. The spectral determination of chlorophylls a and $b$, as well as total carotenoids, using various solvents with spectrophotometers of different resolution. J. Plant Physiol. 1994, 144, 307-313. [CrossRef]

43. Doan, T.T.; des Tureaux, T.H.; Rumperl, C.; Janeau, J.; Jouquet, P. Impact of compost, vermicompost and biochar on soil fertility, maize yield and soil erosion in Northern Vietnam: A three year mesocosm experiment. Sci. Total Environ. 2015, 514, 147-154. [CrossRef]

44. Garcia-Ruiz, R.; Ochoa, V.; Gómez-Muñoz, B.; Alvarez de la Puente, J.M. Does the composted olive mill pomace increase the sustainable N use of olive oil cropping? In Proceedings of the 16th Nitrogen Workshop on Connecting Different Scales of Nitrogen Use in Agriculture, Torino, Italy, 28 June-1 July 2009.

45. Morra, L.; Pizzolongo, G.; Baiano, S.; Pentangelo, A. Comparison of olive pomace and biowaste composts in vegetable cropping systems. Ital. J. Agron. 2013, 8, 206-216. [CrossRef]

46. Paz-Ferreiro, J.; Fu, S.; Méndez, A.; Gascó, G. Interactive effects of biochar and the earthworm Pontoscolex corethrurus on plant productivity and soil enzyme activities. J. Soil. Sediments 2014, 14, 483-494. [CrossRef]

47. Jones, L.; Rousk, J.; Edwards-Jones, G.; DeLuca, T.H.; Murphy, D.V. Biochar-mediated changes in soil quality and plant growth in a three year field trial. Soil Biol. Biochem. 2012, 45, 113-124. [CrossRef]

48. Rajkovich, S.; Enders, A.; Hanley, K.; Hyland, C.; Zimmermann, A.R.; Lehmann, J. Corn growth and nitrogen nutrition after additions of biochars with varying properties to a temperate soil. Biol. Fertil. Soils 2012, 48, 271-284. [CrossRef]

49. Chatterjee, S.; Santos, F.; Abiven, S.; Itin, B.; Stark, R.E.; Jeffrey, A.B. Elucidating the chemical structure of pyrogenic organic matter by combining magnetic resonance, mid-infrared spectroscopy and mass spectrometry. Org. Geochem. 2012, 51, 35-44. [CrossRef]

50. Windeatt, J.H.; Ross, A.; Williams, P.T.; Forster, P.; Nahil, M.A.; Singh, S. Characteristics of biochars from crop residues: Potential for carbon sequestration and soil amendment. J. Environ. Manag. 2014, 146, 189-197. [CrossRef] [PubMed]

51. Meschewski, E.; Holm, N.; Sharma, B.K.; Spokas, K.; Minalt, N.; Kelly, J.J. Pyrolysis biochar has negligible effects on soil greenhouse gas production, microbial communities, plant germination, and initial seedling growth. Chemosphere 2019, 228, 565-576. [CrossRef] [PubMed]

52. Spokas, K.A.; Cantrell, K.B.; Novak, J.M.; Archer, D.W.; Ippolito, J.A.; Collins, H.P.; Boateng, A.A.; Lima, I.M.; Lamb, M.C.; McAloon, A.J.; et al. Biochar: A synthesis of its agronomic impact beyond carbon sequestration. J. Environ. Qual. 2012, 41, 973-989. [CrossRef] [PubMed]

53. Ding, Y.; Liu, Y.; Liu, S.; Li, Z.; Tan, X.; Huang, X.; Zeng, G.; Zhou, L.; Zheng, B. Biochar to improve soil fertility. A review. Agron. Sustain. Dev. 2016, 36, 36. [CrossRef]

54. Olszyk, D.; Johnson, M.; Shiroyama, T.; Novak, J.; Cantrell, K.; Watts, D. Effects of Biochar Feedstock and Pyrolysis Temperature on Growth of Corn, Soybean, Lettuce and Carrot; Society for Environmental Toxicology and Chemistry, US Environmental Protection Agency: Vancouver, BC, Canada, 2014. 
55. Gravel, V.; Dorais, M.; Menard, C. Organic potted plants amended with biochar: Its effect on growth and Pythium colonization. Can. J. Plant Sci. 2013, 93, 12171227. [CrossRef]

56. Khan, T.F.; Salma, M.U.; Hossain, S.A. Impacts of Different Sources of Biochar on Plant Growth Characteristics. Am. J. Plant Sci. 2018, 9, 1922-1934. [CrossRef]

57. Revell, K.T.; Maguire, R.O.; Agblevor, F.A. Influence of poultry litter biochar on soil properties and plant growth. Soil Sci. 2012, 177, 402-408. [CrossRef]

58. Awadi, Y.M.; Lee, S.S.; Ahmed, M.B.M.; Vu, N.T.; Farooq, M.; Seop, K.I.; Kim, H.S.; Vithanage, M.; Usman, A.R.A.; Al-Wabel, M.; et al. Biochar, a potential hydroponic growth substrate, enhances the nutritional status and growth of leafy vegetables. J. Clean. Prod. 2017, 156, 181-188. [CrossRef]

59. McClellan, T.; Deenik, J.; Uehara, G.; Antal, M. Effects of Flashed Carbonized Macadamia Nutshell Charcoal on Plant Growth and Soil Chemical Properties. In Proceedings of the ASA-CSSA-SSA International Annual Meetings, New Orleans, LA, USA, 6 November 2007; p. 194.

60. Atkinson, C.J.; Fitzgerald, J.D.; Hipps, N.A. Potential mechanisms for achieving agriculture benefits from biochar application to temperate soils: A review. Plant Soil 2010, 337, 11-18. [CrossRef]

61. Clough, T.J.; Condron, L.M. Biochar and the nitrogen cycle: Introduction. J. Environ. Qual. 2010, 39, 1218-1223. [CrossRef] [PubMed]

62. Novak, J.M.; Busscher, W.J.; Watts, D.W.; Laird, D.A.; Ahmedna, M.A.; Niandou, M.A.S. Short-term $\mathrm{CO} 2$ mineralization after additions of biochar and switchgrass to aTypic Kandiudult. Geoderma 2010, 154, 281-288. [CrossRef]

63. Lehmann, J.; Pereira, J.; Steiner, C.; Nehls, T.; Zechs, W.; Glaser, B. Nutrient availability and Leaching in the Archaeological Anthrosols and Ferrosol of the Central Amazon Basin: Fertilizer, Manure and Charcoal Amendments. Plant Soil 2003, 249, 343-357. [CrossRef]

64. Hernández, A.; Castillo, H.; Ojeda, D.; Arras, A.; López, J.; Sánchez, E. Effect of vermicompost and compost on lettuce production. Chil. J. Agric. Res. 2010, 70, 583-589. [CrossRef]

65. Helgason, B.; Larney, F.L.; Janzen, H.H.; Olson, B.M. Nitrogen dynamics in soil amended with composted cattle manure. Can. J. Soil Sci. 2007, 87, 43-50.

66. Wolkowski, R. Nitrogen management considerations for landspreading municipal solid waste compost. J. Environ. Qual. 2003, 32, 1844-1850. [CrossRef]

67. Hartl, W.; Erhart, E. Crop nitrogen recovery and soil nitrogen dynamics in a 10- year field experiment with biowaste compost. J. Plant Nutr. Soil Sci. 2005, 168, 781-788. [CrossRef]

68. Gutser, R.; Ebertseder, T.; Weber, A.; Schraml, M.; Schmidhalter, U. Short-term and residual availability of nitrogen after long-term application of organic amendments on arable land. J. Plant Nutr. Soil Sci. 2005, 168, 439-446. [CrossRef]

69. Echer, M.M.; Zoz, T.; Rossol, C.D.; Steiner, F.; Castagnara, D.D.; Lana, M.C. Plant density and nitrogen fertilization in Swiss chard. Hortic. Bras. 2012, 30, 703-707. [CrossRef]

70. EFSA. Opinion of the scientific panel on contaminants in the food chain on a request from the European commission to perform a scientific risk assessment on nitrate in vegetables. EFSA J. 2008, 6, 689. [CrossRef]

71. Colla, G.; Kim, H.J.; Kyriacou, M.C.; Rouphael, Y. Nitrate in fruits and vegetables. Sci. Hortic. 2018, 237, 221-238. [CrossRef]

72. Herencia, J.F.; Ruiz-Porras, J.C.; Melero, S.; Garcia-Galavis, P.A.; Morillo, E.; Maqueda, C. comparison between organic and mineral fertilization for soil fertility levels, crop macronutrient concentration and yield. Agron. J. 2007, 99, 973-983. [CrossRef]

73. Matallana- Gonzales, M.C.; Martinez-Tomè, M.J.; Isasa, M.E.T. Nitrate and nitrite content in organically cultivated vegetables. Food Addit. Contam. Part B 2010, 3, 19-29. [CrossRef]

74. Bosch, M.N.; Alvarez, J.M.; Rodriguez, M.L.P. Influencia del tipo de abono sobre la acumulacion de nitrato en vegetales. Ann. Bromatol. 1991, 2, 215-220.

75. Raigon, M.D.; Gento, A.D.; Sierra, J.M.C.; Vidal, E. Comparacion de parametros de calida en hortalizas de hoja ancha bajo sistemas de produccion ecologica y convencional. Agric. Vergel 2002, 241, $26-32$.

76. Barcelos, C.; Machado, R.M.A.; Alves-Pereira, I.; Ferreira, R.; Bryla, D.R. Effects of substrate type on plant growth and nitrogen and nitrate concentration in spinach. Int. J. Plant. Biol. 2016, 7, 6325. [CrossRef]

77. Conesa, E.; Niñirola, D.; Vicente, M.J.; Ochoa, J.; Bañón, S.; Fernández, J.A. The influence of nitrate/ammonium ratio on yield quality and nitrate, oxalate and vitamin $C$ content of baby leaf spinach and bladder campion plants grown in a floating system. Acta Hortic. 2008, 843, 269-273. [CrossRef] 
78. Tischner, R. Nitrate uptake and reduction in higher and lower plants. Plant Cell Environ. 2000, 23, 1005-1024. [CrossRef]

79. Liu, Y.J.; Tong, Y.P.; Zhu, Y.G.; Ding, H.; Smith, E.A. Leaf chlorophyll readings as an indicator for spinach yield and nutritional quality with different nitrogen fertilizer applications. J. Plant Nutr. 2006, 29, 1207-1217. [CrossRef]

80. Castellanos, J.Z.; Uvalle-Bueno, J.X.; Aguilar-Santelises, Y.A. Manual de Interpretación de Análisis de Suelos, Aguas Agrícolas, Plantas ECP, 2nd ed.; INIFAP: Chapingo, Mexico, 2000.

(C) 2020 by the authors. Licensee MDPI, Basel, Switzerland. This article is an open access article distributed under the terms and conditions of the Creative Commons Attribution (CC BY) license (http://creativecommons.org/licenses/by/4.0/). 